\title{
Long-term settlement induced by EPB tunnelling studied with numerical simulations
}

\author{
MACIEJ OCHMAŃSKI \\ Faculty of Civil Engineering, Silesian University of Technology, Gliwice, Poland
}

\begin{abstract}
Long-term settlement induced by EPB tunnelling studied with numerical simulations. Long-term settlement induced by tunnelling in soft cohesive subsoil is rarely considered as a subject for research despite substantial evidence that it increases considerably after construction. The paper aims to investigate the time effects of tunnelling with an earth pressure balance (EPB) shield by means of analysing subsoil deformation with the most up-to-date numerical tool. A three-dimensional numerical model with a detailed description of the geometrical and mechanical characteristics of the tunnelling process and the various materials involved was built. The computational model validated on a real-case was then used to simulate tunnelling in different groundwater conditions prior to construction. That was followed by a simulation of groundwater drawdown conditions after tunnelling with impermeable and permeable tunnel linings. The calculations show the development of the settlement over time in different groundwater conditions together with the significant influence of the permeability of the tunnel.
\end{abstract}

Key words: numerical simulations, EPB shield, long-term settlement

\section{INTRODUCTION}

There is substantial evidence that the settlement continues to increase up to several years after the construction of tunnels in soft cohesive subsoil (O'Reilly et al. 1991, Bowers et al. 1996, Harris
2002, Mair 2008, Wu et al. 2011, Ng et al. 2013). This aspect of tunnelling becomes particularly important when considering that long-term settlement, which is generally caused by consolidation, may constitute $30-90 \%$ of total settlement (Shirlaw 1995). There are two factors leading to tunnelling-induced consolidation, with the first one related to the technological processes significantly disturbing subsoil around the cavity. Mechanized tunnelling in cohesive soils is mainly carried out using earth pressure balance (EPB) shields that excavate soil with a rotary cutterhead and are pushed forward against previously installed segmental lining by a set of hydraulic jacks. During this process, a grout backfilling is injected at the tail of the shield to fill the circumferential void between the lining extrados and cavity boundary. Immediately after injection, grout behaves as a liquid and with the progress of hydration turns into a relatively strong and stiff material preventing further deformation of the cavity. Subsoil consolidation caused by the imbalance between stress state in the soil and the pressure of the grout is limited to relatively small portions of soil around the cavity and the intensity of the induced effect is determined by 
the pressure difference between these two materials. The second factor leading to the consolidation settlement is that tunnels act as drains introducing new boundary conditions at the cavity contour. This results in a negative excess pore water pressure induced in the surrounding soil, thus an increase in the effective stress in the soil leads to the consolidation process (Ward and Thomas 1965, Palmer and Belshaw 1980, Harris 2002). Additionally, the existence of the thin grouting layer around the segmental lining has a rather limited effect on its water-tightness, especially over the long-term (Mair 2008). Water flows into the tunnel through the grouting layer and the joints between the lining segments. It is often observed that the internal surface of the lining is visibly wet even though auxiliary measures are applied to make it watertight. The final long-term settlement resulting from the combination of both factors generally occurs over a much larger area and the settlement trough profile is much deeper and wider with little curvature compared to the short-term one (Mair and Taylor 1997).

In densely urbanized cities, cyclic and transient seasonal effects are drastically limited by the presence of buildings and concrete pavements, roads which efficiently reduce the migration of water from rainfall and prevent the evaporation of moisture from the subsurface. Therefore, the level of the groundwater table is influenced by the fluctuation of river levels, leakage from water mains, deep-well pumping and the presence of nearby tunnels. The change in the groundwater level prior to tunnelling may also lead to significant changes in the ground settlement as noted by Mair (2008). Even more significant effects may be induced by a groundwater drawdown after tunnelling, this effect is manifested not only by additional long-term settlement but also by the rotation of the lining segments and the change in the structural forces in that elements.

The analyses of the tunnelling process mainly refer to the almost immediate short-term effects and are mainly carried out using empirical approaches (Peck 1969) derived from a wide database of evidence. On the other hand, analytical closed-form solutions are not frequently used in view of their rather limited capabilities which are reduced to elasticity and rarely plasticity with questionable assumptions that ignore much of the modern knowledge concerning soil behaviour. The most sophisticated tools are numerical simulations that have recently gained popularity due to their impressive capabilities which allow for the introduction of complex geometry of the problem and include various contact behaviours between different elements and sophisticated constitutive models for natural and artificial materials. Furthermore, the progressive development of contemporary IT technology allows, especially thanks to parallel computing, coupled problems to be solved with precisely described geometry discretized with hundreds of thousands of finite elements. Moreover, according to the provisions contained in the current codes of practice (e.g. in the European Union CEN, 2004), geotechnical design should always consider the effects induced by the changes in the groundwater table as it leads to time-related effects, one of the consequence is increased earth pressure acting on the lining (ASCE 
1984). Despite that, most of the analyses of the tunnelling process even using sophisticated numerical tools still refer to the immediate response and neglect to analyse the long-term effects related to consolidation which are assumed to be rather negligible.

The aim of the paper is to analyse the effects related to long-term consolidation as a result of shield tunnelling and the groundwater table drawdown. The paper demonstrates the capabilities of the most up-to-date and realistic reproduction of the tunnelling process with EPB technology by means of numerical simulations. An automated numerical model introduced with a script prepared in python objected-oriented language for commercial Abaqus ${ }^{\mathrm{TM}}$ FEM code developed by Ochmański et al. (2018) is used here to allow for fast solutions with a strong theoretical basis. After a brief description of the computational model, a validation based on a real case study of the Metropolitan Rapid Transit Authority (MRTA) project in Bangkok (Suwansawat 2002, Surarak 2010, Sirivachiraporn and Phienwej 2012, Likitlersuang et al. 2013) is presented. Finally, the long-term effects related to the consolidation of soil induced by the tunnelling process are analysed together with the effects of the groundwater drawdown by means of the ground surface settlement. Analyses are performed introducing impermeable and fully-permeable tunnel linings.

\section{COMPUTATIONAL MODEL}

The computational model is introduced in the commercial Abaqus ${ }^{\mathrm{TM}}$ (Hibbitt and Sorensen 2001) FEM code as a three-dimensional symmetrical problem as depicted in Figure 1. Simulations are

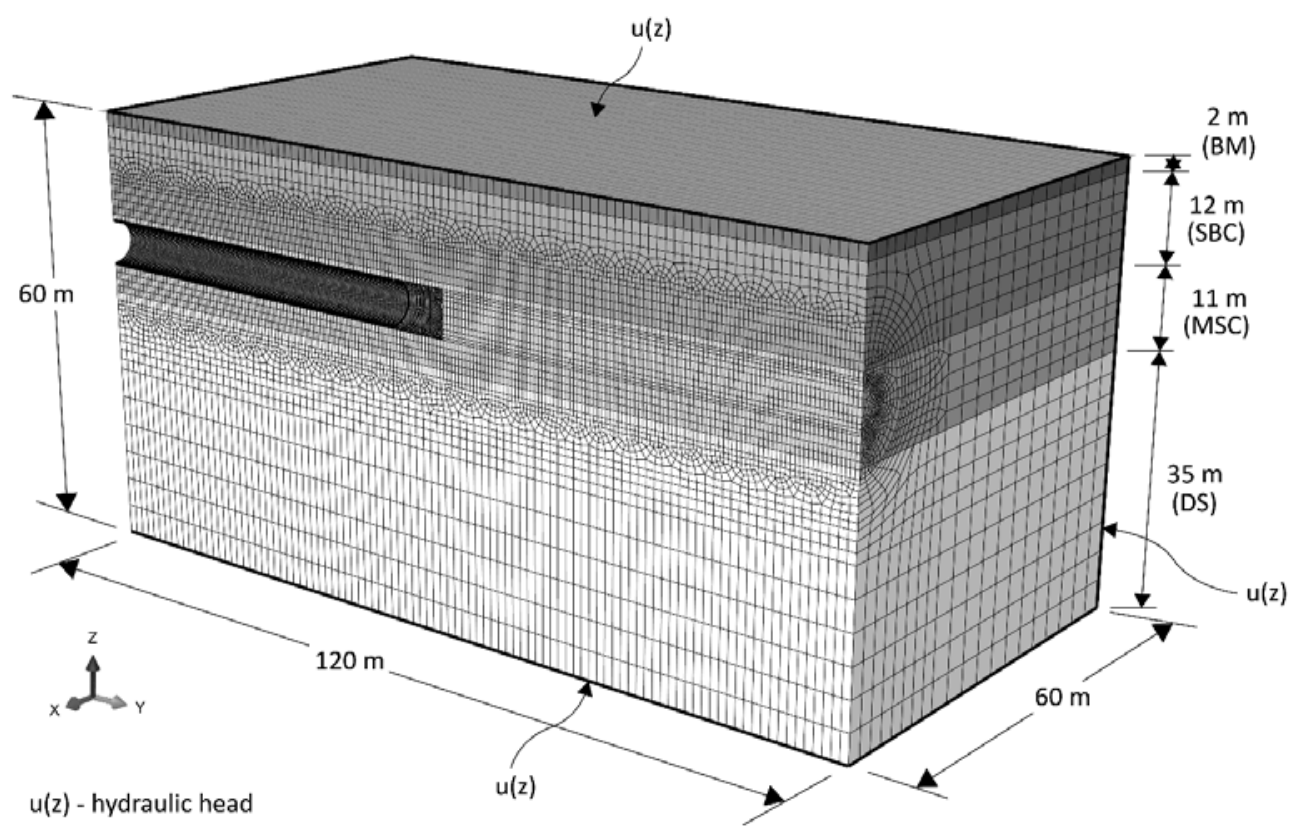

FIGURE 1. A three-dimensional symmetrical FEM model of tunnel drilled with the EPB shield 
fully automatized and controlled by a script written in the Python programming language. The model introduced presents an attempt to describe in as precise as possible all of the components of the EPB technology which allows for the elimination of many subjective assumptions which are typical of the simulation of this process, such as the fictitious boundary conditions of prescribed displacements at the cavity boundary to reproduce volume loss. For the sake of brevity, only a brief description of the computational model characteristics is given here, in order to learn about the fine details the reader is referred to the work of Ochmański et al. (2018).

\section{Geometry of the model}

The introduced model produces the possibility of reproducing any possible geometrical setup of a tunnel and subsoil including e.g. the stratification of the subsoil, irregular surface shapes, curved tunnel alignment etc. The model boundaries are fixed at the distance which preserves their minimum influence on the region of stress concentration according to Gunn's (1993) recommendations. Depending on the model complexity, its geometry may be discretized with eight-node linear bricks or with 10-node quadratic tetrahedral elements.

\section{Subsoil}

The role played by the subsoil behaviour due to the fluctuations of the groundwater table on the overall response of the geotechnical model is undeniably important. The initial distribution of the effective stress in the case of horizontal subsoil layers is computed using the $K_{0}$ procedure, while the initial pore water pressure is calculated assuming hydraulic heads at the boundaries of the model and known value of the permeability coefficient of each layer. The nonlinear, irreversible stress-displacement response of the subsoil in the presented model is described by means of the hypoplastic constitutive models (Gudehus et al. 2008) freely available as a FORTRAN implementation at the website of Soilmodels project (www.soilmodels.com). Specifically, the von Wolffersdorff (1996) hypoplastic model was used for the coarse-grained materials and the Mašín (2005) model for the fine-grained materials. To calibrate the former one, 13 parameters need to be assigned, while for the later one, 12 parameters are necessary. Furthermore, to include increased stiffness in the small-strain range, an extension called the intergranular strain concept (ISC) (Niemunis and Herle 1997) has been introduced. Subsoil layers are assumed to be fully saturated with water flow described by the well-known Darcy's law.

\section{Tunnel heading with the EPB shield}

An essential element of the tunnel heading machine is a conical shield tapering off towards the end as depicted in Figure 2 with other elements forming an altogether realistic reproduction of the tunnelling process with the EPB shield. The shield's deformations are determined by a linear-elastic behaviour, whereas its interaction with the surrounding soil is simulated as a "hard contact" in the normal direction and with Coulomb friction in the tangential direction. The tunnel face is supported by a hydrostatically distributed pressure applied to an impermeable membrane at the front surface (Müeller-Kirchenbauer 1977) 


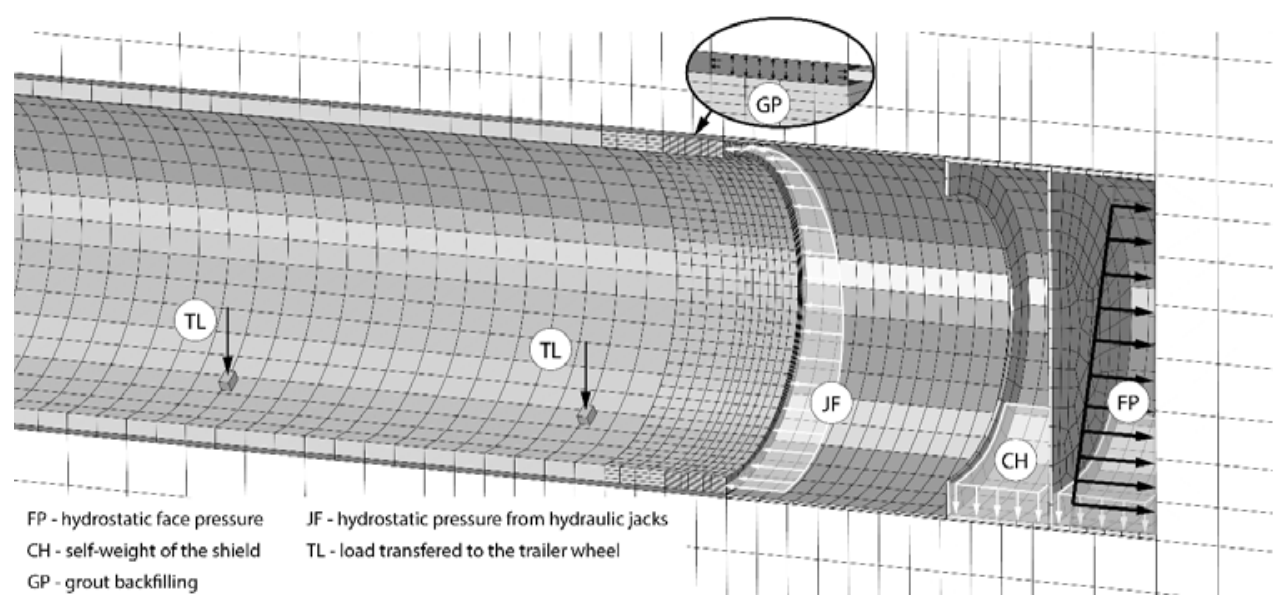

FIGURE 2. Definition of the computational model for tunnelling with the EPB shield (Ochmański et al. 2018)

transferring pressure to both the soil skeleton and pore fluid. The self-weight of the shield is applied to the bottom part of the shield's internal surface as a resultant pressure from all devices located within the shield.

A tunnel lining is introduced as a cylinder with a specific diameter and thickness. Segmentation of the lining has been considered only along the tunnel axis with a frictional contact between the adjacent rings, thus omitting stiffness reduction due to the radial joints. Whereas, the material of lining has been assumed to be linear-elastic with parameters typical for mature material of precast concrete elements. Face supporting pressure, forces generated by the hydraulic jacks necessary to push the shield forward and the frictional force generated at the soil-shield interface have been applied as a resultant pressure to the transversal outer surface of the last installed ring.

The grout backfilling of the circumferential void formed between an extrados of the lining and the boundary of the cavity has been simulated by a layer of finite elements with the initial stress state hydrostatically varying corresponding to the injection pressure. The mechanical response of this material has been assumed to be isotropic linear-elastic with a time-dependent stiffness based on the relationships defined by Meschke et al. (1996). The initial nil volume change corresponding to the liquid state of the grout has been accounted for by fixing the value of the Poisson's ratio to 0.499 (to overcome singularity for 0.5 ) with a progressive drop in time up to a value of 0.2 specific for the solid material.

The presence of the backup trailer following the shield has been simulated as a set of concentrated forces applied to the single cubic elements which represent the weight of the gantry cranes.

\section{Computational steps}

The tunnelling process is schematized by a repetitive sequence of two discrete steps, specifically for the shield advancement and lining installation. Each step is 
computed by assuming a transient coupled stress-displacement analysis with pore fluid diffusion. In the step of shield advancement, displacements are confined to the back of the shield, pushing it ahead of the current face position, together with the corresponding shift of all of the applied loads, i.e. the shield's self-weight and backup-trailer loads transmitted to the lining. In the next step, the excavation of the soil is simulated by the deactivation of the finite elements accompanied by the hydrostatic pressure applied to the newly exposed face and the activation of the lining with tail void backfilling elements.

After the simulation of the tunnel construction, an additional two steps of a long-term consolidation analysis are introduced. During the first step, the excess pore pressure generated during tunnelling is dissipated, whereas the second step refers to conditions of the groundwater drawdown simulated by applying the new boundary conditions of the pore pressure at the bottom surface of the soil block.

\section{Computational unit}

A computationally expensive coupled stress-displacement analysis simulating the seepage flow problem with geometry discretized using around 400 thousands finite elements $(\sim 1.5$ million DOF) was carried out on two nodes of the Prometheus supercomputer being a part of the Polish grid infrastructure. The message-passing library (MPI) parallelization of the element operations and equation solution with the direct sparse solver resulted in a significant reduction of the simulation time ( 230 vs $53 \mathrm{~h}$ ) compared to modern personal computers equipped with the Intel i7 CPU (12 cores) and 64 GB of memory.

\section{VALIDATION OF THE MODEL}

\section{- CASE STUDY}

A project called Blue Line was undertaken by the Metropolitan Rapid Transit Authority (MRTA) in the area of Bangkok, it served as a reference case for the validation of the computational model. It consisted of 18 cut-and-cover stations connected by two twin tunnels (Northbound and Southbound) each about 20-kilometer long and drilled with EPB shields. Validation was performed within a short section of the line characterized by a sequence of the following subsoil layers: weathered crust and backfill material (BM), Bangkok soft clay (BSC), medium stiff to stiff clay (MSC), and medium dense to very dense sand (DS). The mechanical behaviour of each layer from small to large strain range has been calibrated with reference to the rich database of field and laboratory tests reported e.g. by Balasubramaniam et al. (1976), Balasubramaniam and Hwang (1980) or Seah and Koslanant (2003). The initial shear stiffness profile through depth has been calibrated from the above tests, while the stiffness degradation curves for each layer have been fitted to pass through a strain thresholds $-\gamma_{0.7}$ (ratio at which $G / G_{\max }$ is equal to 0.7 ) which were taken from studies of Likitlersuang et al. (2013). A detailed explanation of the constitutive model calibration along with its performance is presented in the work of Ochmański (2016). For the sake of brevity, the results of the calibration are presented here only for the medium stiff to stiff clay (MSC) as depicted in Figure 3. The state parameters for all the Bangkok subsoil layers with the calibrated parameters of the hypoplastic constitutive models are presented in Table 1. 


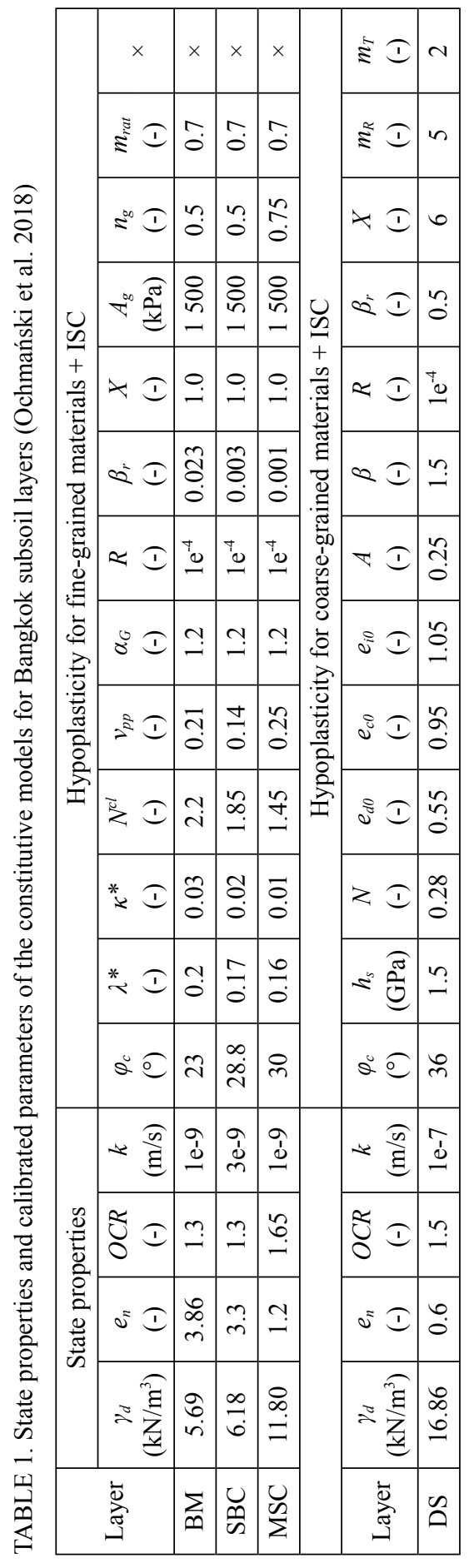

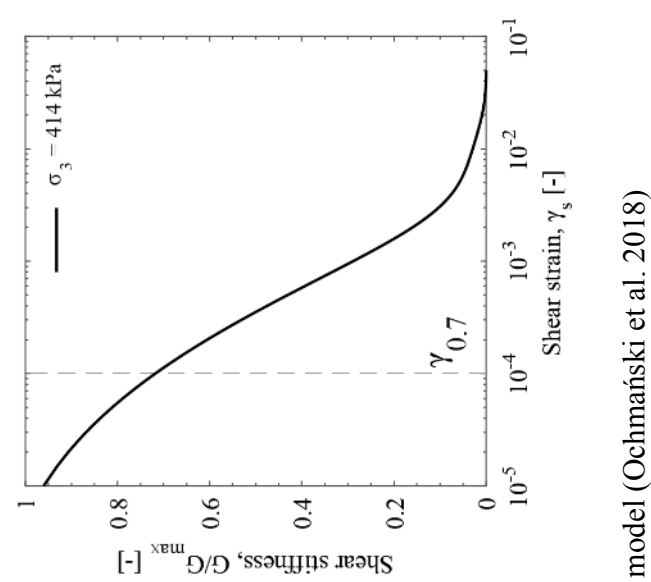
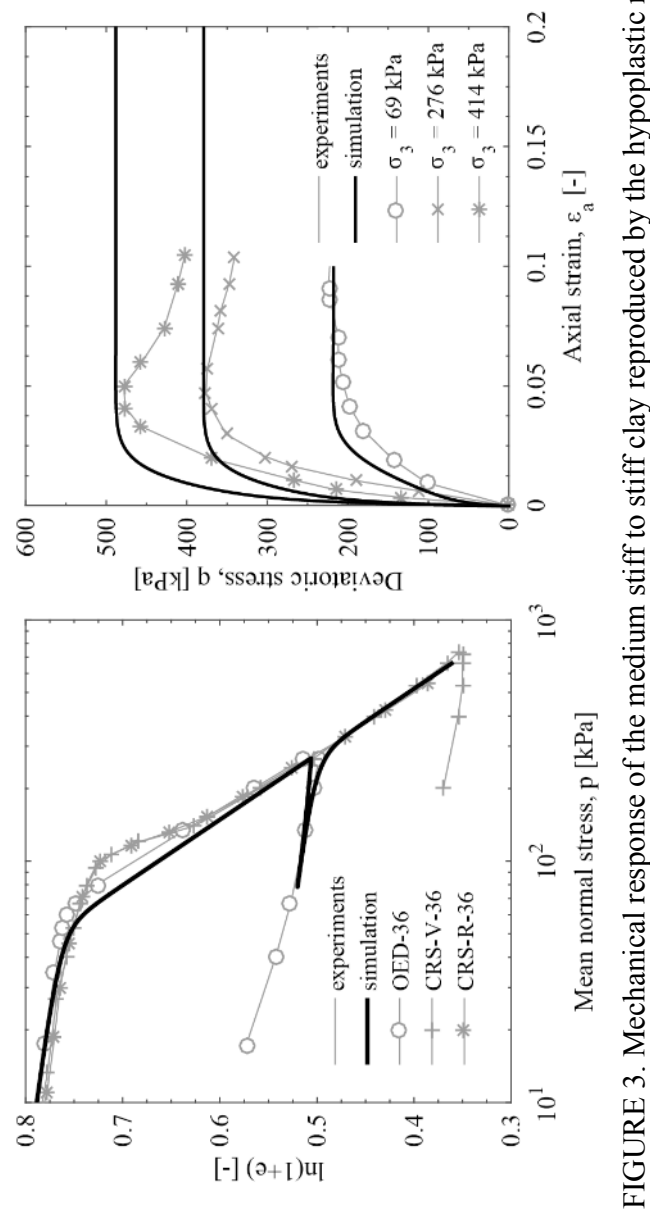
Simulation of the EPB tunnelling has been validated on the Southbound tunnel drilled before the Northbound one. In the analysed section, a shield with a diameter of $6.43 \mathrm{~m}$ at a depth of $18 \mathrm{~m}$ was used

to construct a tunnel of $6.3 \mathrm{~m}$ in a diameter (external lining diameter without including tail void). The parameters characterizing the computational model summarized in Table 2, were taken from

TABLE 2. Parameters of the model adopted to simulate tunnelling with the EPB shield of the MRTA project

\begin{tabular}{|c|c|c|c|c|c|c|c|}
\hline Parameter & Symbol & Unit & Value & Parameter & Symbol & Unit & Value \\
\hline \multicolumn{4}{|c|}{ Subsoil } & \multicolumn{4}{|c|}{ Tail void backfilling } \\
\hline Width & $W$ & $\mathrm{~m}$ & 60 & $\begin{array}{l}\text { Ratio of initial } \\
\text { stiffness* }\end{array}$ & $E_{1} / E_{28}$ & - & 0.6 \\
\hline Length & $L$ & $\mathrm{~m}$ & 120 & $\begin{array}{l}\text { Stiffness after } 28 \\
\text { days* }\end{array}$ & $E_{28}$ & $\mathrm{GPa}$ & 5 \\
\hline Height & $H$ & $\mathrm{~m}$ & 60 & Poisson's ratio & $v_{28}$ & - & 0.49 \\
\hline Number of soil layers & $n$ & - & 4 & Grout density* & $p_{g r}$ & $\mathrm{~kg} / \mathrm{m}^{3}$ & 1800 \\
\hline $\begin{array}{l}\text { Distance to tunnel } \\
\text { springline }\end{array}$ & $z_{0}$ & $\mathrm{~m}$ & 18 & $\begin{array}{l}\text { Grouting pressure } \\
\text { (axis) }\end{array}$ & $G_{P}$ & $\mathrm{kPa}$ & 170 \\
\hline \multicolumn{4}{|c|}{ Shield } & \multicolumn{4}{|c|}{ Tunnel lining } \\
\hline Diameter at the front & $D_{c h 1}$ & $\mathrm{~m}$ & 6.43 & Outer diameter & $D_{l}$ & $\mathrm{~m}$ & 6.3 \\
\hline Diameter at the back & $D_{c h 2}$ & $\mathrm{~m}$ & 6.43 & Thickness & $T_{l}$ & $\mathrm{~m}$ & 0.3 \\
\hline Length & $L_{s}$ & $\mathrm{~m}$ & 8.35 & Ring width & $W_{l}$ & $\mathrm{~m}$ & 1.2 \\
\hline Conicity & $\delta$ & $\mathrm{m}$ & 0 & Young's modulus & $E_{l}$ & $\mathrm{GPa}$ & 31.5 \\
\hline $\begin{array}{l}\text { Front shield } \\
\text { thickness* }\end{array}$ & $T_{f s}$ & $\mathrm{~m}$ & 0.08 & Poisson's ratio & $v_{l}$ & - & 0.2 \\
\hline Tail shield thickness* & $T_{t s}$ & $\mathrm{~m}$ & 0.04 & Bulk density & \begin{tabular}{l|}
$p_{l}$ \\
\end{tabular} & $\mathrm{kN} / \mathrm{m}^{3}$ & 25 \\
\hline Front shield length & $L_{f s}$ & $\mathrm{~m}$ & 4.0 & \multicolumn{4}{|c|}{ Backup trailer } \\
\hline Tail shield length & $L_{t s}$ & $\mathrm{~m}$ & 4.35 & Total length* & \begin{tabular}{|l|}
$L_{t r}$ \\
\end{tabular} & $\mathrm{~m}$ & 72 \\
\hline Young's modulus & $E_{s h}$ & $\mathrm{GPa}$ & 200 & Total weight* & $F_{t t_{-} \text {tot }}$ & $\mathrm{kN}$ & 3980 \\
\hline Poisson's ratio & $v_{s h}$ & - & 0.3 & Transversal spacing* & $S_{t r}$ & $\mathrm{~m}$ & 3.0 \\
\hline Overcut & $D_{e x c}$ & $\mathrm{~m}$ & 0.02 & Number of forces* & $F_{t r \_n}$ & - & 9 \\
\hline $\begin{array}{l}\text { Gap at the shield } \\
\text { back }\end{array}$ & $g_{t}$ & $\mathrm{~m}$ & 0.065 & Longitudinal spacing* & $L f_{t r}$ & $\mathrm{~m}$ & $\begin{array}{c}3,7.5,7.5,3 \\
15,3,15,3,15\end{array}$ \\
\hline $\begin{array}{l}\text { Total self-weight of } \\
\text { the shield* }\end{array}$ & $F_{s}$ & $\mathrm{kN}$ & 3000 & Forces* & $F_{t r}$ & $\mathrm{kN}$ & $\begin{array}{l}230,230,230 \\
280,280,270 \\
270,100,100\end{array}$ \\
\hline $\begin{array}{l}\text { Coulomb friction } \\
\text { coefficient* }\end{array}$ & $\mu$ & - & 0.20 & \multicolumn{4}{|c|}{ Construction steps } \\
\hline Frictional force & $W_{M}$ & $\mathrm{kN}$ & 8700 & Penetration rate & $t_{e x c}$ & $\mathrm{~m} / \mathrm{h}$ & 1.5 \\
\hline $\begin{array}{l}\text { Face pressure at the } \\
\text { axis }\end{array}$ & $F_{P}$ & $\mathrm{kPa}$ & 120 & Stand-still phase & $t_{s t d}$ & $\mathrm{~h}$ & 0.5 \\
\hline $\begin{array}{l}\text { Gradient of the face } \\
\text { pressure }\end{array}$ & $F_{P, g r}$ & $\mathrm{kPa} / \mathrm{m}$ & 15.7 & \multicolumn{4}{|c|}{$x$} \\
\hline
\end{tabular}

* Values assumed based on similar studies (Kasper and Meschke 2004). 
a

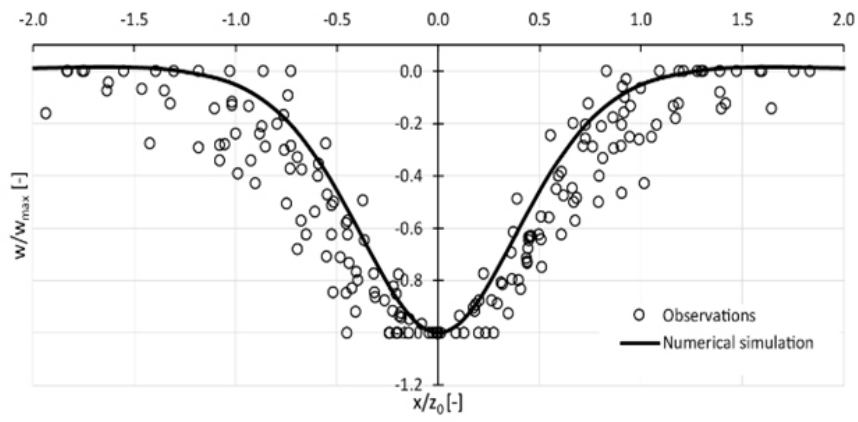

b

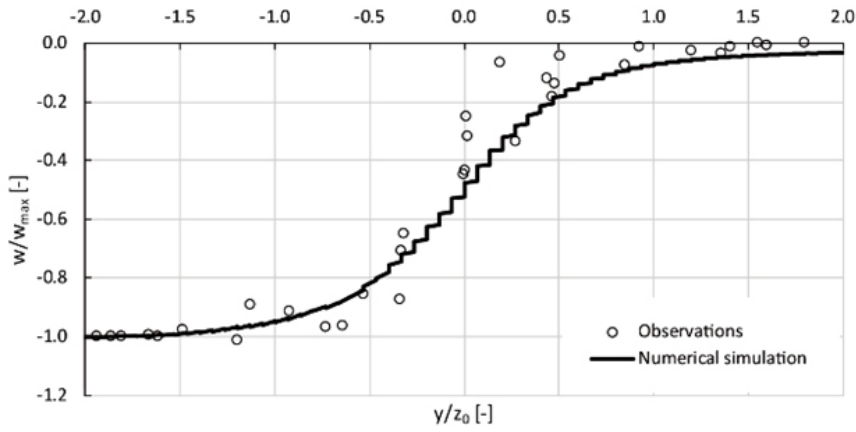

FIGURE 4. Surface settlement profiles obtained from simulations in the transversal (a) and longitudinal section (b) compared with observations

the literature describing the case study (Suwansawat 2002, Suwansawat and Einstein 2007) and partly assumed based on similar studies (Kasper and Meschke 2004).

The surface settlement generated during tunnelling obtained from numerical simulations is presented in Figure 3 together with a cloud of points representing observations from the real case. The results obtained for the longitudinal section are presented up to the moment when the shield reached a distance from the reference section equal to double the depth of the tunnel $(36 \mathrm{~m})$. The settlement trough profile (Fig. 4a) obtained from a simulation with the maximum value of $19 \mathrm{~mm}$ and volume loss of $1.2 \%$ are slightly different from those obtained from evidences, i.e. $13.5 \mathrm{~mm}$ and $1.0 \%$. The settlement profile is narrower compared to the mean characteristic of observations, however, it still fits into the cloud of points. On the other hand, the longitudinal profile fits well with the observations.

\section{SETTLEMENT INDUCED \\ BY TUNNELLING IN DIFFERENT GROUNDWATER CONDITIONS}

In order to investigate the influence of the groundwater conditions on the long-term settlement induced by tunnelling, the following scenarios have been analysed: groundwater drawdown 
conditions prior to tunnelling; and the conditions of hydrostatically distributed pore water pressure followed by groundwater drawdown after tunnelling. The latter analysis has been extended by the simulation of long-term consolidation with and without drainage conditions at the tunnel boundaries representing impermeable and fully permeable lining.

Groundwater drawdown results in a change of stress transfer between the soil skeleton and pore water. The vertical component of the pore water pressure is transferred to the horizontal one by a ratio of lateral pressure equal to 1.0 , while the horizontal component of the effective stress is computed from the vertical one with the use of the $K_{0}$ coefficient which is usually lower than unity. In this way, an obvious increase of the vertical effective stress due to the reduction of pore water pressure results in an increase of horizontal effective stress but to a lesser extent than the reduction of pore water pressure; thus, in the conditions of groundwater drawdown, the total

a

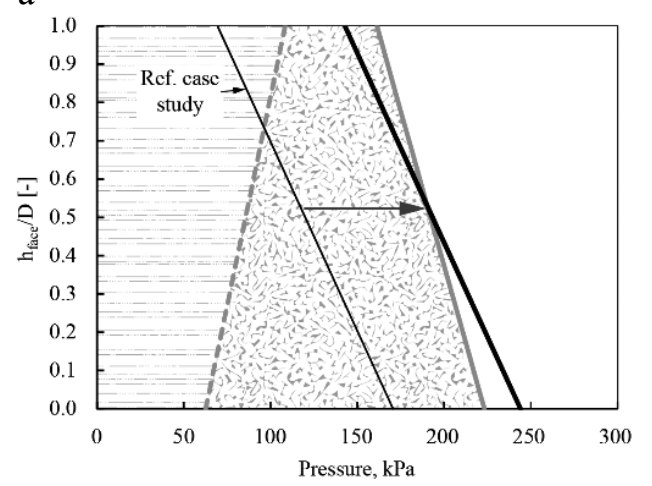

b

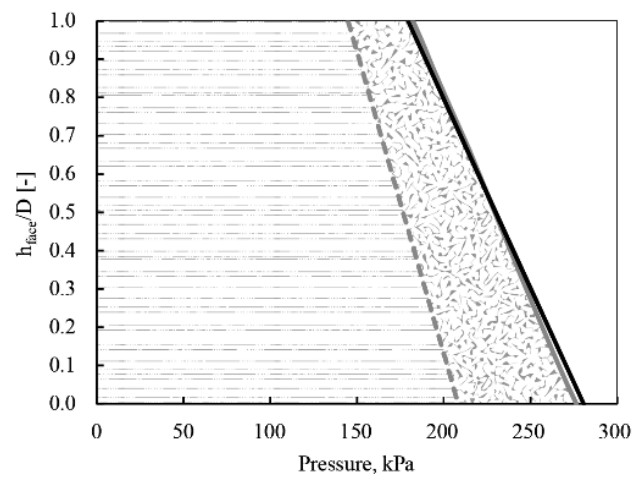

Pore water pressure

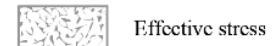

$\longrightarrow$ Face pressure

FIGURE 5. Face pressure applied in a simulation of groundwater drawdown conditions (a) prior to, and (b) after tunnelling 
Figure $5 \mathrm{~b}$. In this way, face pressure is equal to the horizontal total stress component and a comparison between both cases may be carried out.

The short-term settlement of the subsoil induced during tunnelling in both groundwater conditions plotted as longitudinal and transversal settlement profiles are depicted in Figure 6. Additionally, settlement profiles from the simulation in groundwater drawdown conditions with face pressure as in the reference case study $\left(F_{p}=120 \mathrm{kPa}\right)$ are also given. The results presented in the form of longitudinal profiles refer to the deformations induced until the shield reached a distance from the reference section equal to three times the tunnel depth $(54 \mathrm{~m})$, while results in the transversal section correspond to the situation when the reference section is behind the face at the same distance of $3 \cdot z_{0}$. The latter ones are vertically and horizontally scaled with reference to their maximum values and depth to the springline, respectively. The results in the short-term present a typical deformation pattern induced by tunnel excavation depicted at the ground surface as a settlement trough, with some differences related to the different initial water-bearing conditions. Simulations of tunnelling in initial

$\mathrm{a}$

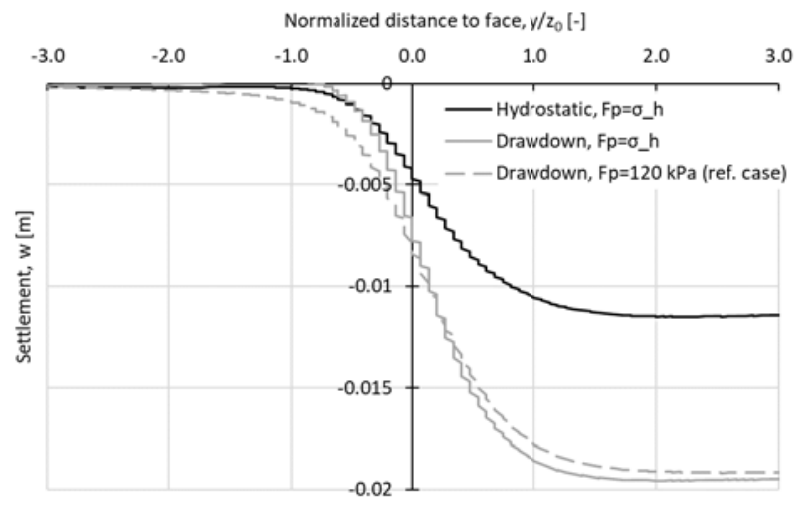

b

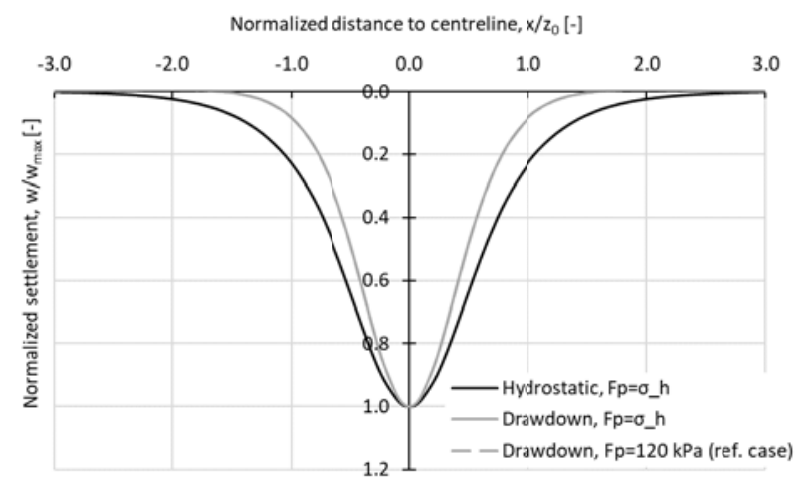

FIGURE 6. Short-term surface settlement presented in the (a) longitudinal section and (b) transversal section 
groundwater drawdown conditions show the influence of the face pressure on the reduction of pre-convergence, thus limiting surface settlement ahead of the tunnel face. At the same time, after passing the reference section $\left(y / z_{0} \geq 0\right)$ by the shield, increased face pressure barely influences the settlement profile and none is observed in the transversal section. Comparing the results of the simulation in groundwater drawdown conditions, with an increase in face pressure compared to a value similar to the horizontal stress component $\left(F_{p}=195 \mathrm{kPa}\right)$, with those from the simulation in hydrostatic groundwater conditions with the corresponding face pressure, significant differences are observed. In the latter conditions, surface settlement recorded in the longitudinal profile is almost twice smaller (11 vs $19 \mathrm{~mm})$ as that from the former simulation in groundwater drawdown conditions. It is connected with an increased horizontal total stress component at the tunnel level, while the vertical component remains unchanged.
The load transferred from the soil to the lining is more uniform with a better lateral confinement, which results in a lower lining deformation followed by a reduction of the subsoil settlement. On the other hand, an increase in the settlement trough width in the transversal section is observed. In Figure 7 a 3D contour plot of settlements is presented, but for the sake of brevity, only for the simulation of tunnelling in groundwater drawdown conditions.

Simulation of the subsoil consolidation after tunnel construction reveals further differences between the studied cases. The longitudinal and transversal settlement profiles are plotted together with the contour plots of excess pore water pressure generated during tunnelling in drawdown and hydrostatic groundwater conditions in Figure 8. Relative settlement induced after tunnelling in drawdown conditions (Fig. 8a) reaches $13 \mathrm{~mm}$, which constitute about $65 \%$ of the short-term settlement, while consolidation for tunnelling

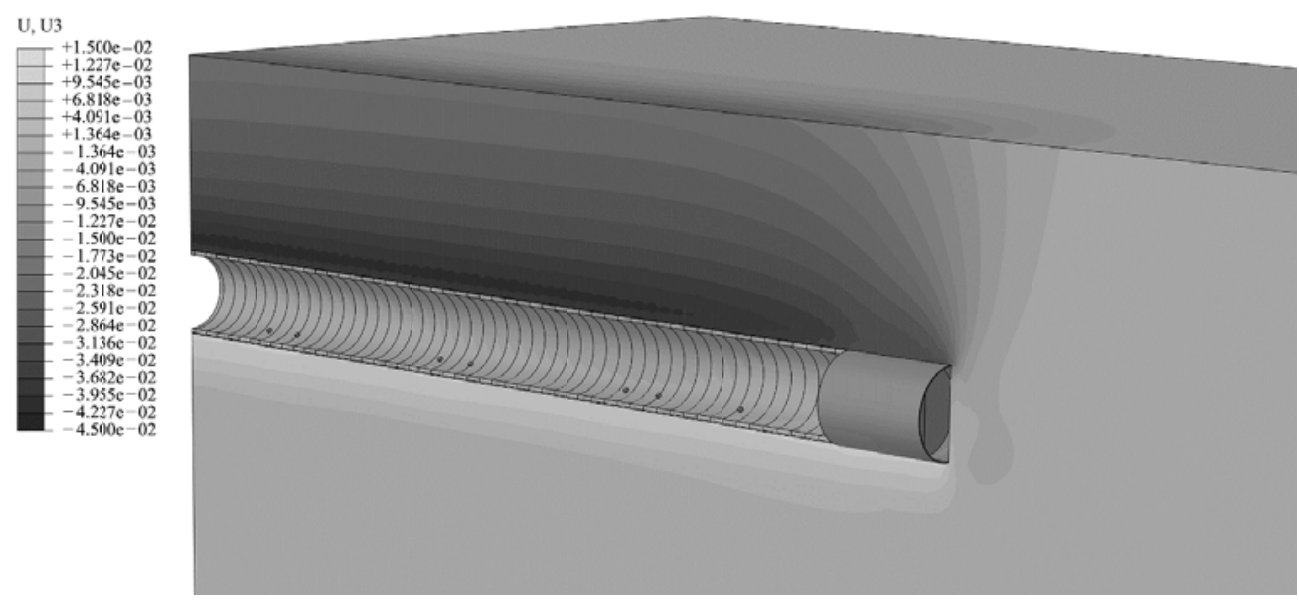

FIGURE 7. Contour plot of the settlement from numerical analysis with groundwater drawdown conditions prior to tunnelling with increased face pressure $\left(F_{p} \approx \sigma_{h}\right)$ 


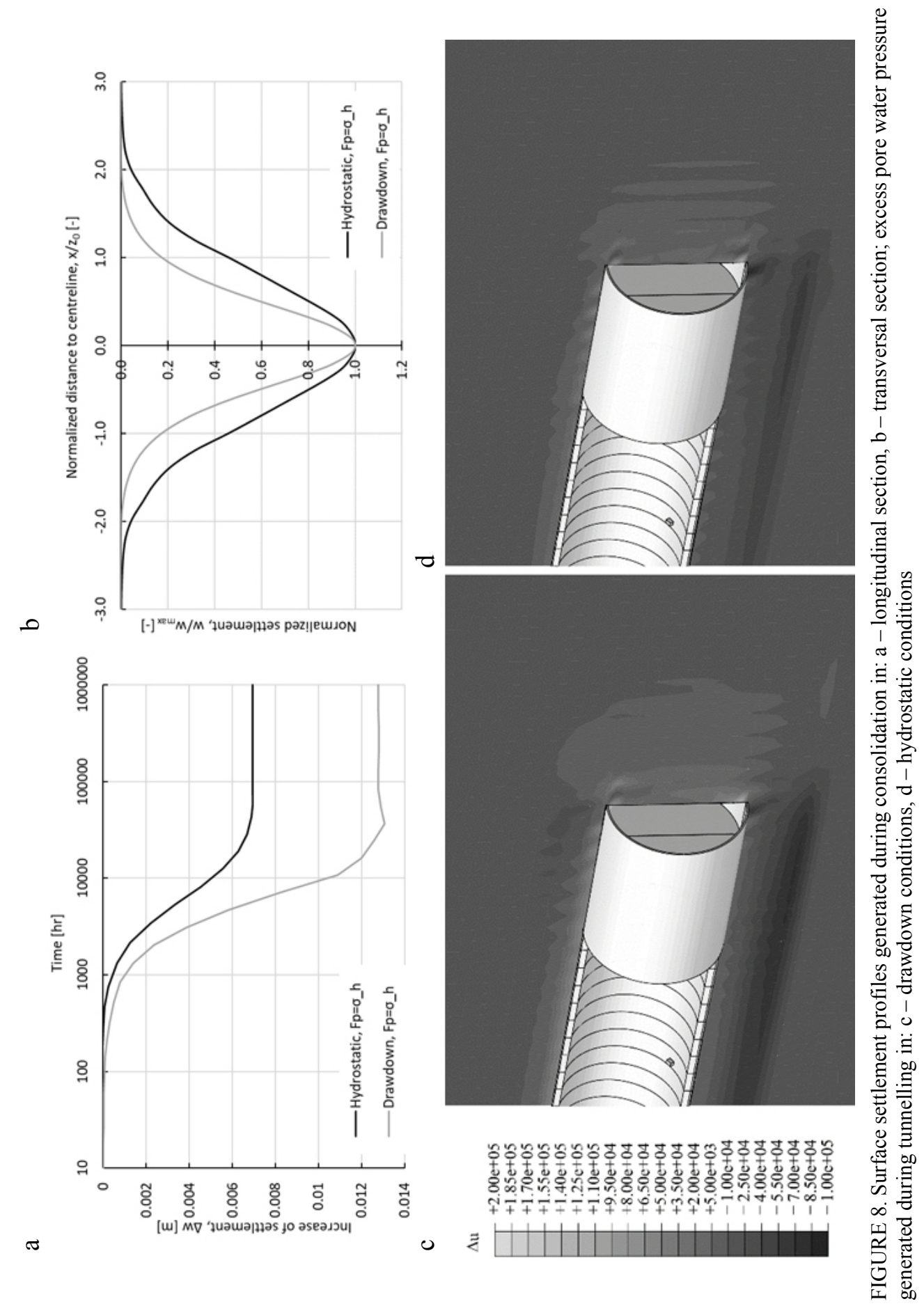


in hydrostatic groundwater conditions is slightly more intensive and settlement increases by $7 \mathrm{~mm}$, which is $80 \%$ of the initial value. Looking at the transversal section of the trough profile (Fig. 8b) for tunnelling in hydrostatic groundwater conditions, an increase in its width by almost $100 \%$ is observed resulting in a significant reduction of its curvature. The reason for this behaviour is that a more intensive consolidation process is induced in the soil around the tunnel in groundwater drawdown conditions as confirmed by excess pore pressure plotted for both cases in Figures 8c and $8 \mathrm{~d}$. In both cases, the maximum excess pore water pressure is generated ahead of the face and around the lining in the upper half, whereas a higher value is observed for the initial drawdown conditions. On the other hand, minimal excess pore pressure appears under the tunnel at a distance approximately equivalent to the tunnel radius with a concentration located directly under the shield, and similar to the simulation with initial drawdown conditions indicates extremum. This may be explained by the fact that face pressure at the crown and invert is respectively lower and higher than the horizontal component of the total stress by around $30 \mathrm{kPa}$ due to their different gradients as depicted in Figure 5.

Subsoil consolidation is influenced by the permeability of the lining introduced in the presented simulations by means of the pore pressure boundary conditions applied at the tunnel perimeter. The presented results refer to the simulation of tunnelling with hydrostatic and drawdown groundwater conditions. The settlement profiles in the longitudinal and transversal sections, and distribution of the steady-state pore water pressure in the case of fully-permeable lining are presented in the Figure 9. The observations indicate a progressive increase of settlement for the fully permeable lining by $0.65 \mathrm{~m}$ for the tunnel in hydrostatic groundwater conditions and by $0.22 \mathrm{~m}$ for the tunnel in drawdown conditions, which is a result of water flow to the tunnel from surrounding subsoil. In both cases additional settlement is at least one order of magnitude larger than that in the case of the tunnel with an impermeable lining. The difference of settlement between both cases is related again to the intensity of the consolidation which, in drawdown conditions, is lower due to less negative excess pore water pressure build-up after the introduction of a drainage boundary at the tunnel cavity. The contour plots of the pore water pressure presented in the Figure $9 \mathrm{c}$ and $\mathrm{d}$ indicates a lowering of the free-field pressure and its drop around the tunnel. Besides that, in both cases similar nonnegligible widening of the transversal profiles of the settlement trough quantified by a $20 \%$ increase of the distance to the inflection point is observed when a permeable lining is introduced.

Effects of the groundwater table lowering on the ground surface settlement are depicted in Figure 10. In both analysed cases, a progressive increase of the free-field settlement after the introduction of new boundary conditions of pore pressure at the bottom of the soil block may be observed. In the case of tunnelling with an impermeable lining, settlement increases by almost $1.3 \mathrm{~m}$, while for a permeable lining, additional settlement $(0.9 \mathrm{~m})$ is lower than in the 

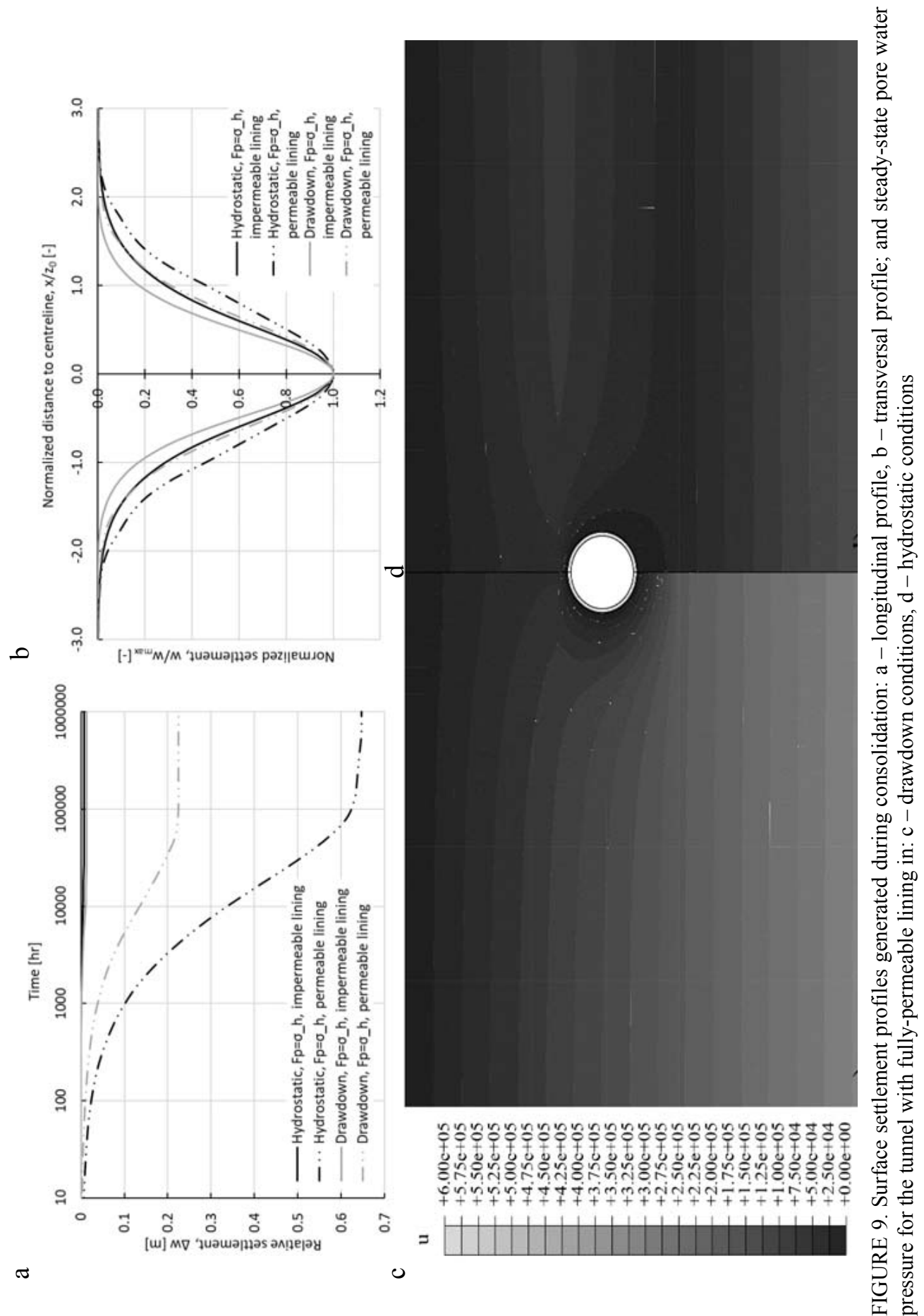

0$$
\text { נ. }
$$ 
a

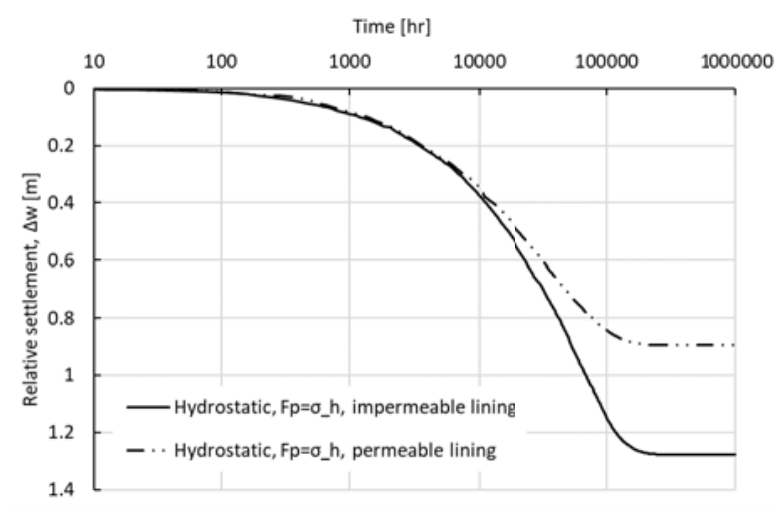

b

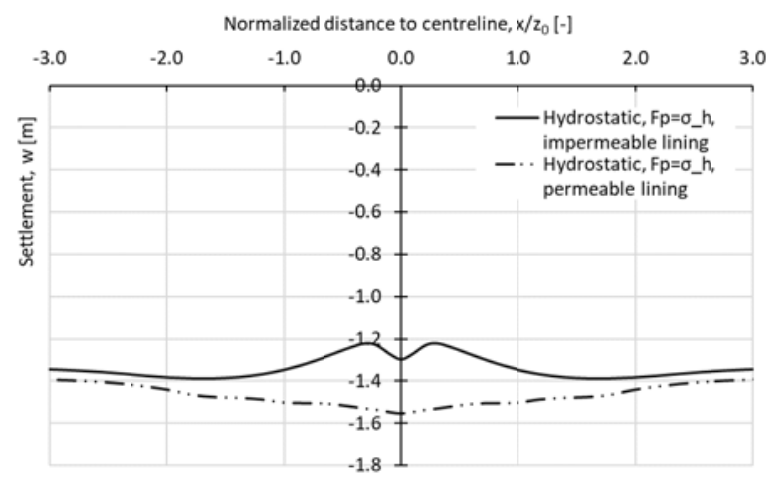

FIGURE 10. Surface settlement profiles resulting from groundwater drawdown: a - longitudinal profiles and $b$ - transversal profiles

previous case due to the earlier consolidation of the soil in close proximity to the tunnel. After filtering out the free-field settlement, it may be noticed that the tunnel with an impermeable lining leads to an unfavourable heave of the ground surface due to the existence of rather stiff lining comparing to the soft subsoil, which undergoes the consolidation process. The intensity of this effect depends on the relative stiffness of the lining and will increase with a lower overburden depth and in the case of deep tunnels, it may even be negligible. On the other hand, a fully-permeable lining induces additional settlement, which nevertheless results in a much smoother transversal settlement profile with less curvature.

The transversal profiles expressed as a total settlement show that in both impermeable and fully-permeable linings a similar amount of the free-field settlement equal to around $1.4 \mathrm{~m}$ occurs. This significant increase of settlement observed during the lowering of the pore water pressure is a consequence of the very compressible soil layer $(\lambda=0.4$ and $e=3.3$ ) with a large thickness. These results are in accordance with the estimation completed by Nutalaya et al. (1989) indicating $1.6 \mathrm{~m}$ of long-term settlement due to deep well pumping from the Bangkok subsoil. 


\section{CONCLUSIONS}

The paper presents the most up to date and realistic reproduction of tunnelling process with EPB technology by means of automated FEM simulations applied to investigate effects related to different groundwater conditions on the induced ground deformations. The computational model, successfully validated with a real case study, has been used to simulate long-term settlement induced by EPB tunnelling in hydrostatic and groundwater drawdown conditions with impermeable and fully-permeable lining.

The presented analyses have shown that both short- and long-term settlements are significantly influenced by different groundwater conditions and demonstrated the importance of the lining permeability. During tunnelling in the groundwater drawdown conditions, the positive outcome of a lower face supporting pressure becomes unimportant due to the possible increase of short- as well as long-term settlements. This is a result of the difference between the face pressure gradient and horizontal stress component gradient, leading to insufficient support at the crown and excess pore water pressure build-up around the cavity. In the long-term, the concentration of excess pore water pressure around the tunnel, induces more intensive consolidation of the soil in its close proximity, thus generating further ground deformations. On the other hand, when the fully-permeable lining is introduced, the situation is reversed, generating lower long-term settlement as an effect of tunnelling in already consolidated subsoil due to groundwater drawdown than that which occurs under hydrostatic conditions. The permeability of the lining is not without interest especially when lowering of the groundwater table is induced after tunnel construction. A few centimetres of differential settlement of the ground surface induced during groundwater table lowering has a much larger impact on the response of the existing structures than even an order of magnitude larger freefield settlement. The former, in the case of fully-permeable lining, is smaller, resulting in a smooth transversal profile with little curvature, while in the case of the impermeable lining, the relative heave of the ground surface being for the existing structures much more destructive than the settlement is observed. This effect will depend on the lining stiffness and at the same time will become more important for shallow tunnels with a lower overburden, while for the deep ones it may not even occur.

\section{Acknowledgements}

This research was supported in part by PL-Grid Infrastructure.

\section{REFERENCES}

ASCE 1984: Guidelines for tunnel lining design. ASCE, New York.

BALASUBRAMANIAM A.S., CHAUDHRY A.R., HWANG M., UDDIN W., LI Y.G. 1976: State boundary surface for weathered and soft Bangkok Clay. Austral. Geomech. J. 6 (1): 43-50.

BALASUBRAMANIAM A.S., HWANG Z.-M. 1980: Yielding of weathered Bangkok clay. Soils Found. 20 (2): 1-15.

BOWERS K.H., MILLER D.M., NEW B.M. (1996): Ground movement over three years at the Heathrow Express Trial Tunnel. In: R.J. Mair, R.N. Taylor (Eds.), Geotechnical aspects of underground construction in soft ground. Balkema, Rotterdam: 647-652. 
EN 1997-1. Eurocode 7. Geotechnical design. GUDEHUS G., AMOROSI A., GENS A., HERLE I., KOLYMBAS D., MAŠIN D., WOOD D.M., NIEMUNIS A., NOVA R., PASTOR M., TAMAGNINI C., VIGGIANI G. 2008: The soilmodels.info project. Int. J. Num. Anal. Meth. Geomech. 32 (12): 1571-1572.

GUNN M.J. 1993: The prediction of surface settlement profiles due to tunnelling. In: G.T. Houlsby, A.N. Schofield (Eds.), Predictive soil mechanics. In: Proceedings of the Wroth memorial symposium, 27-29.07.1992, St. Catherine's College, Oxford. Thomas Telford: 304-316.

HARRIS D.I. 2002: Long term settlement following tunnelling in overconsolidated London Clay. In: R. Kastner, F. Emeriault, D. Dias, A. Guilloux (Eds.), Geotechnical aspects of underground construction in soft ground. Spécifique, Lyon: 393-398.

HIBBITT K., SORENSEN 2001: ABAQUS/ /Standard User's Manual. ABAQUS/Standard User's Manual. Hibbitt, Karlsson \& Sorensen.

KASPER T., MESCHKE G. 2004: A 3D finite element simulation model for TBM tunnelling in soft ground. Int. J. Num. Anal. Meth. Geomech. 28 (14): 1441-1460.

LIKITLERSUANG S., TEACHAVORASINSKUN S., SURARAK C., OH E., BALASUBRAMANIAM A. 2013: Small strain stiffness and stiffness degradation curve of Bangkok Clays. Soils Found. 53 (4): 498-509.

MAIR R.J. 2008: Tunnelling and geotechnics: new horizons. Géotechnique 58 (9): 695-736.

MAIR R.J., TAYLOR R.N. 1997: Bored tunnelling in the urban environment: State-of-the-art report and theme lecture. In: Proceedings of 14th International Conference on Soil Mechanics and Foundation Engineering, Hamburg. Vol. 4: 2353-2385.

MAŠÍN D. 2005: A hypoplastic constitutive model for clays. Int. J. Num. Anal. Meth. Geomech. 29 (4): 311-336.

MESCHKE G., KROPIK C., MANG H.A. 1996: Numerical analyses of tunnel lining by means of a viscoplastic material model for shotcrete. Int. J. Num. Meth. Eng. 39 (18): 3145-3162.

MÜELLER-KIRCHENBAUER H. 1977: Stability of slurry trenches in inhomogeneous subsoil. In: Proceedings of the 9th International Conference on Soil Mechanics and Foundation Engineering. Tokyo. Vol. 2: 125-132.
NG C.W.W., LIU G.B., LI Q. 2013: Investigation of the long-term tunnel settlement mechanisms of the first metro line in Shanghai. Can. Geotech. J. 50 (6): 674-684

NIEMUNIS A., HERLE I. 1997: Hypoplastic model for cohesionless soils with elastic strain range. Mech. Cohesive-Frictional Mat. 2 (4): 279-299.

NUTALAYA P., YONG R.N., CHUMNANKIT T., BUAPENG S. 1989: Land subsidence in Bangkok during 1978-1988. In: Workshop on Bangkok Land Subsidence - What is Next? Bangkok: 1-48.

O'REILLY M.P., MAIR R.J., ALDERMAN G.H. 1991: Long-term settlements over tunnels: an eleven-year study at Grimsby. In: Proceedings of Conference Tunnelling '91, London: 55-64.

OCHMAŃSKI M. 2016: Numerical analyses of the effects of tunnels construction. $\mathrm{PhD}$ thesis, Silesian University of Technology, Gliwice [typescript].

OCHMAŃSKI M., MODONI G., BZÓWKA J. 2018: Automated numerical modelling for the control of EPB technology. Tunn. Undergr. Sp. Tech. 75: 117-128.

PALMER J.H.L., BELSHAW D.J. 1980: Deformations and pore pressure in the vicinity of a precast, segmented, concrete-lined tunnel in clay. Can. Geotech. J. 17 (2): 174-184.

PECK R.B. 1969: Deep excavations and tunnelling in soft ground. In: Proceedings of the 7th International Conference on Soil Mechanics and Foundation Engineering: 225-290.

SEAH T.H., KOSLANANT S. 2003: Anisotropic consolidation behavior of soft Bangkok clay. Geotech. Test. J. 26 (3): 266-276.

SHIRLAW J.N. 1995: Observed and calculated pore pressures and deformation induced by earth pressure balance shield. Can. Geotech. J. 32: 181-189.

SIRIVACHIRAPORN A., PHIENWEJ N. 2012: Ground movements in EPB shield tunneling of Bangkok subway project and impacts on adjacent buildings. Tunn. Undergr. Sp. Tech. 30: $10-24$.

SURARAK C. 2010: Geotechnical Aspects of the Bangkok MRT Blue Line Project. PhD thesis, Griffith School of Engineering, Brisbane [typescript].

SUWANSAWAT S. 2002: Earth Pressure Balance (EPB) Shield Tunneling in Bangkok: Ground Response and Prediction of Surface Settle- 
ments Using Artificial Neural Networks. PhD thesis, Massachusetts Institute of Technology [typescript].

SUWANSAWAT S., EINSTEIN H.H. 2007: Describing settlement troughs over twin tunnels using a superposition technique. J. Geotech. Geoenviron. Eng. 133 (4): 445-468.

WARD W.H., THOMAS H.S.H. 1965: The development of earth loading and deformation in tunnel linings in London Clay. In: Proceedings of 6th International Conference on Soil Mechanics Foundation Engineering, Toronto. Vol. 2: 432-436.

von WOLFFERSDORFF P.A. 1996: A hypoplastic relation for granular materials with a predefined limit state surface. Mech. Cohesive-Frictional Mat. 1 (3): 251-271.

WU H., XU Y., SHEN S., CHAI J. 2011: Long-term settlement behavior of ground around shield tunnel due to leakage of water in soft deposit of Shanghai. Front. Arch. Civil Eng. China 5 (2): 194-198.

Streszczenie: Analizy numeryczne dhugoterminowego osiadanie gruntu wywolanego drązeniem tunelu tarcza wyrównanych ciśnień gruntowych. Mimo istnienia wielu dowodów przedstawiających rozwój w czasie osiadań wywołanych procesem tunelowania w spoistym podłożu gruntowym, tematyka ta rzadko jest przedmiotem badań naukowych. Celem artykułu jest zbadanie zmiany w czasie efektów wywołanych drążeniem tunelu tarczą wyrównanych ciśnień gruntowych (ang. earth pressure balance - EPB) przez przeprowadzenie analiz numerycznych deformacji podłoża gruntowego. W tym celu zbudowano trójwymiarowy model numeryczny szczegółowo odzwierciedlający proces tunelowania, geometrię analizowanego problemu oraz odpowiedź mechaniczną różnych materiałów. Model obliczeniowy został zweryfikowany $\mathrm{w}$ odniesieniu do rzeczywistego tunelu wydrążonego w Bangkoku, a następnie wykorzystany do symulacji procesu tunelowania w różnych warunkach gruntowo-wodnych. Przeprowadzone symulacje przedstawiają wpływ obniżenia zwierciadła wody gruntowej po wydrążeniu tunelu przy założeniu w pełni przepuszczalnej i nieprzepuszczalnej segmentowej obudowy tunelu na rozwój osiadań podłoża gruntowego w czasie.

Stowa kluczowe: symulacje numeryczne, tarcza EPB, konsolidacja

$M S$ received 23.01.2018

MS accepted 04.06.2018

\author{
Author's address: \\ Maciej Ochmański \\ Katedra Geotechniki i Dróg \\ Wydział Budownictwa \\ Politechnika Śląska \\ ul. Akademicka 5, 44-100 Gliwice \\ Poland \\ e-mail: maciej.ochmanski@polsl.pl
}

